\title{
A Conceptual Review of Engineering Consultancy Practice (ECP) Business Model
}

\author{
Justin Lai \\ Department od Structure and Materials, Faculty of Civil Engineeering \\ University of Technology Malaysia, Johor, Malaysia \\ Rosli Zin \\ Department od Structure and Materials, Faculty of Civil Engineeering \\ University of Technology Malaysia, Johor, Malaysia \\ Khairulzan Yahya \\ Department od Structure and Materials, Faculty of Civil Engineeering \\ University of Technology Malaysia, Johor, Malaysia
}

\begin{abstract}
The Malaysian government has highlighted liberalization for seventeen (17) service sub-sectors in phases, including architectural and engineering services. Liberalization offers opportunities to transfer of capital, expertise, and technology to domestic firms to expand business. As a result, the local Engineering Consultancy Practices are facing challenges in enhancing their competitiveness in sustain their business in the industry. In a sense, proper business model is one of the main criteria to enhance the business performance. This paper aims to contribute to this overlooked but important research line. Semantically, this paper comprehensively reviews the Engineering Consultancy Practice business model from various aspects and applications. The preliminary finding reveals that the concept of developing new ECP business core values is essential to enhance the existing ECP business performance. Eleven (11) business model core values are introduced in this study, verified through systematic triangulation analysis. The outcome can be used to become a guideline for the engineering consultancy practices in Malaysia.
\end{abstract}

Keywords: Engineering Consultancy Practice (ECP), Business Model, Malaysia

\section{INTRODUCTION}

It has been realized that the services sector has evidently become one of the major contributors to the Gross Domestic Product (GDP) in Malaysia. It has recorded a remarkable performance in 2013, 51.44 per cent (RM50 billion) of the total investment of RM 98.4 billion is contributed by the services sector (Department of Statistic Malaysia, 2013). Services sector covered a wide array of activities which includes hotels, restaurants, transport, storage, communication, financing, insurance, real estate, business services, social, and personal services. In the World Trade Organization (WTO), construction is also included (Union Budget, 2013). Meanwhile, the construction industry has contributed 4.16 per cent of GDP 2013, indicated a big scale of business performance among services sector and construction.

The construction embedded in services sector is referring to the engineering consultancy which included architectural, civil and structural, mechanical and electrical consultancy and etc. The engineering consultancy services play a vital role in the construction industry. It is 
important to ensure that the construction project is able to construct accordingly. However, the ability of the business management in engineering consultancy is crucial to enhance the performance the particular consultancy firm performance and hence improve the performance of the construction industry.

In order to enjoy greater business opportunities arise from the global liberalization of services, Malaysian services industries have to adapt an open market competition. In this context, the services sector has to build up their efficiency, productivity, and competitiveness by all means to increase foreign participation while adapting global best practice standards. The greatest challenges to the local service sector are the ability to attract foreign investment, especially Engineering Consultancy Practice (ECP) firms.

The majority of the services sector is categorized under Small Medium Enterprises (SME) with an annual turnover less than RM20 million and the number of employees ranging from 5 person to 75 persons (new definition of SME in Malaysia, effective on $1^{\text {st }}$ January 2014). In general, SMEs are facing the similar difficulties in lack of skills, insufficient resources, strategic planning and inspiring vision, standard and quality control and low productivity. These weaknesses have greatly shown in ECP due to the majority of the ECP firms are small in size, limited staffs, high human resource turnover and highly competitive in consultancy market. Therefore, it is essential to explore what is the existing ECP business model practiced in Malaysia?

"Thousands of engineers in the country will have to close shop if the Government allows nonprofessionals to own and operate consultancy practices", The Institution of Engineers' Malaysia (IEM) expressed its concern on $12^{\text {th }}$ December 2012 via mass media. IEM President, Vincent Chen has commented that if anyone is allowed to own $100 \%$ equity in an engineering consultancy practice, even a fish monger can start a consultancy firm and hire engineers to work for him, then the professional engineers will have to face greater challenge due to the liberalization of service sub-sectors especially the micro or small scale firms.

According to the survey done by the Board of Engineers Malaysia (BEM) and the Association of Consulting Engineers Malaysia (ACEM) in the year 2003, 97\% of Engineering Consultancy Practice (ECP) is categorised under SMEs. In view of that, competitiveness has become a greater challenge for ECP as a result of liberalisation of service sub-sectors in phases. Building capacity of ECP will be paramount not only towards enhancing the skill and productivity of ECP, but also to ensure the resilience of ECP in sustaining their businesses over the long term amidst an uncertain external environment and competition from liberalisation of markets.

Therefore, it is important to identify the successful business model to be adopted by ECP for building its capacity and competitiveness to face the great challenges due to the liberalisation of services sub-sector.

\section{Engineering Consultancy Practice (ECP)}

\section{LITERATURE REVIEW}

The term "liberalization" is defined as the removal of restrictions. Generally the term comes in pair. As a case in point, trade liberalization is loosely defined as a move towards freer trade through the reduction of tariff and other barriers (Eddy, 2005). Liberalization is different from deregulation in that liberalization does not eliminate government regulations, but encourage more participation in a market to create a competitive environment (Xiao and Wang, 2011). A glimpse review of literature reveals that the concepts of liberalization, privatization and 
globalization are inherently interrelated. Bogdanowicz (1997) as well as Dvornika and Sabolic (2007) have perceived liberalization and privatization as the same concept. Meanwhile, Burguet and Sempere (2003) analyze how trade liberalization affects environmental policies in the context of bilateral trade and imperfect competition. In addition, Angkinand et al. (2010) conducted a cross country analysis that focusing on banking crises as a result of an intermediate degree of liberalization in the financial sector.

On the other hand, it is not uncommon that researchers focus on the relationship between liberalization and several aspects of their study. Yang (2001) investigated the joint effects of trade liberalization and environmental policies on the Taiwan economy. Meanwhile, Bommer and Schulze (1999) revealed why trade liberalization and improved environmental quality are mutually compatible. While Forbes (2003) focused on the implications of liberalization for technology and industrial competitiveness, Mishra and Das (2013) examined the relationship between trade liberalization and wage inequality in India. Awojobi (2013) studied the linkages between financial liberalization and economic growth in Greek. Chikhuri (2013) examined the linkage between agricultural trade liberalization and food security in Sub-Saharan Africa region.

As the name implies, services are no tangible goods and therefore, services sector involves the provision of services businesses and final consumers. In the Malaysian economy, especially its growth and development process, services sector, including some main services sector, such as tourism, telecommunications, education and financial services, have certainly played an important role. As a case in point, the services sector in Malaysian recorded an outstanding performance $(62 \%$ of the $5.3 \%$ economic growth rate) in the year 2005 (9th Malaysia Plan, 2006).

On the other hand, according to data from the Malaysian Investment Development Authority (MIDA), investments in the services sector in January-June 2013 totaled RM58.16 billion with 2,263 approved projects. Of the total investment, Domestic investments in January-June 2013 accounted for 86.4 per cent (RM50.3 billion), while foreign investments were 13.6 per cent (RM7.9 billion). Meanwhile, over the years, the services sector has been rapidly growing its size and contribution to the Malaysian economy as shown in Table 2.1.

In terms of World Trade Organization (WTO) commitments, Malaysia has signed the General Agreement on Trade in Services (GATS), which means local market access will be expanded to foreign service providers. In particular, WTO (2005) defined liberalization of services as a process whereby measures are taken to expand market access to foreign service providers or to diminish discrimination against them vis-à-vis the domestic suppliers. The service sectors are: (1) business services; (2) construction services; (3) educational services; (4) financial services; (5) health and social services; (6) communication services; (7) distribution services; (8) environmental services; (9) tourism services; (10) transport services; (11) recreational services and (12) sporting services.

Despite the commitments, there are generally two types of schedule of specific commitments namely sectoral schedules of commitments (specific sectors) and horizontal schedules of commitments (all sectors), in which countries commit on market access and national treatment (Kaliappan, 2009). The schedules of commitments are: (1) to decide the type of service sector to be liberalized, especially those sensitive and heavily regulated government and monopoly type of service sectors; (2) to specify the market access limitations on the entry of foreign services or service suppliers into the domestic market and (3) to determine the 
market access and national treatment commitments are made for each of the four modes of supply, which as shown in Table 2.2. (Chadha, 2002).

\section{Business Model}

The global economic development has changed the relationship between the customer and supplier. Globalization brings forward communication and computing technology, which opens the global regime, allowing customers to have more choices and better solutions in their business. Therefore, the businesses today should be customer-centric as customers are explored to the lower cost provision of information and solutions through the technology available (David, 2010).

The business environment is not the matter of addressing customers' needs, but also captures the value from providing new products and services. As such, business model has become significantly important to lead the services suppliers to generate value, revenue, reputations and new customers (David, 2010). In the comprehensive review from the previous studies, business model is a guideline for the suppliers (users). Each particular business model should be modified according to the company policies, profits etc. to meet the requirements of the supplier.

A business model articulates the logic and provides data and other evidence that demonstrates how a business creates and delivers value to customers. The issues related to good business model rely on the business strategy to build competitive value to the customers and hence generate profits from there (Don, 2012). As mentioned, a good business model should undergo a series of innovative renovation the suits the model into the company organization. Therefore, ones should thoroughly explore the structural organization, cultural and behavior of the staffs as well as their potential customer in determining business model.

The business performance in Engineering Consultancy Business has raised the concern of professionals in Malaysia. The liberalization of ECP has alarmed the engineers in seeking opportunities in expanding their business. Therefore, it is essential to review the existing business model in ECP in order to enhance their competiveness in construction market. The following section discussed the existing ECP business model in Malaysia.

\section{Business Model in Engineering Consultancy Practice (ECP)}

Business model is defined as a statement of how a company will make money and sustain its profit stream over time (Stewart and Zhao, 2000). Meanwhile, Mayo and Brown (1999) consider business model as a design of key interdependent systems that create and sustain a competitive business. Business model is the heuristic logic that connects technical potential with the realization of economic value (Chesbrough and Rosenbloom, 2002). Morris et. al., (2005) define business model as a concise representation of how an interrelated set of decision variables in the areas of venture strategy, architecture and economics are addressed to create sustainable competitive advantage in defined market. In short, the business model has been mainly implemented to address:

○ The use of information technology in organizations

- Strategic issues

- Innovation and technology management

There are three (3) types of service provider business model widely used by the practitioners, namely, Traditional Business Model, Business Excellence Model and Canvas Business Model. The following section discusses the characteristic of the mentioned business models. 


\section{Traditional Business Model}

Traditional Business Model is the most fundamental business model. It creates a service and sells it either to the customer or to a distributor. The greatest challenge incorporated to this business model is to find the right channel to sell the service. Traditional Business Model is greatly dependent on the direct marketing to customer and sells the service to distributors. However, service provider in terms of engineering consultancy is limited to the appropriate channel in promoting their services. Therefore, the business expansion is limited, depending on the numbers of customer whom need their service (Holger et. al., 2009).

ECP companies today are greater than before. Competitors work to differentiate themselves by striving to meet all requirements, for example trying to have the different thread of job scopes, provide conceivable services or even lower the contract price to secure jobs. From macroeconomic point of view, the unhealthy competition among the ECP and inefficient use of investments in their business are difficult to expand the business (Michael and Eric, 2012).

In Traditional Business Model, the risk is trimmed by a combination of regulation and ethics both aimed at muting competition. With muted competition, the engineers can realistically aspire to a safe upper middle class income, but they are unlikely to become wealthy (Steven, 2013). Majority of the engineers in Malaysia is practicing Traditional Business Model, without knowing the limitation of the model itself. The ECP in Malaysia is conducted by following the business model practiced by their predecessor without assessing the suitability of the model in current industry. In certain extend, some of the ECP might not aware of the business model in their firm as long as the current business practices are able to sustain their business and generate revenue.

\section{Business Excellence Model}

Business Excellence Model (BEM) is first called Total Quality Management model. BEM helps to communicate the importance of "excellence" in all aspects of a business, not only product and process quality. The model is used to assess how well business excellence core values and concepts (the factors of success) are embedded in an organization. These models are now used in at least 83 countries as a key mechanism to help businesses to improve (Robin et. al., 2013).

BEM help organizations to assess the strengths and areas for improvement and provide guidance to practitioners, especially small and medium enterprises (SMEs). BEM provide senior managers with a holistic method with which to manage their business and get buy-in to key decisions that will lead to sustainable and measurable success. BEM serve as the organization's own internal business consultant, ensuring that business decisions incorporate the needs of all stakeholders, are aligned to the organization's objectives and take into account current thought on international best practices.

BEM is widely used in Malaysia. It is similar to the Traditional Business Model that majority of the BEM practitioners are not aware to the types of model they are practicing. This is due to most of the engineers are not alert to business strategy studies, but running the business based on industry culture, business norm and experience.

BEM that practiced in Engineering Consultancy Practice (ECP) Malaysia are focusing on seven criteria (7) namely, leadership, planning, process, customers, information, people and results as shown in Figure 1.0. By comparing to the BEM in Asia, it is found that the criteria are slightly different among the countries based on the firm's interest and industry needs. 
Lai, J., Zin, R., \& Yahya, K. (2014). A conceptual review of engineering consultancy practice (ECP) business model. Archives of Business Research, 2(4), $161-173$

Table 1.0: Criteria of Business Excellence Models in Asia

\begin{tabular}{|c|c|c|c|c|c|c|}
\hline No & $\begin{array}{c}\text { Hong Kong, } \\
\text { Indonesia, Pakistan, } \\
\text { Philipines, Thailand, } \\
\text { and Sri Lanka }\end{array}$ & Japan & Singapore & Malaysia & $\begin{array}{c}\text { Republic of } \\
\text { China }\end{array}$ & India \\
\hline & $\begin{array}{l}\text { 2011-2012 Baldridge } \\
\text { Criteria } \\
\text { Performance } \\
\text { Excellence }\end{array}$ & $\begin{array}{l}\text { Japan Quality } \\
\text { Award Criteria }\end{array}$ & $\begin{array}{l}\text { Singapore BE } \\
\text { Framework }\end{array}$ & $\begin{array}{l}\text { Malaysia BE } \\
\text { Framework }\end{array}$ & $\begin{array}{l}\text { ROC National } \\
\text { Quality Award } \\
\text { Framework }\end{array}$ & $\begin{array}{l}\text { EFQM } \\
\text { Excellence } \\
\text { Model }\end{array}$ \\
\hline 1 & Leadership & $\begin{array}{l}\text { Leadership, } \\
\text { Social } \\
\text { Responsibilities }\end{array}$ & Leadership & Leadership & Leadership & Leadership \\
\hline 2 & Strategic Planning & $\begin{array}{l}\text { Strategic } \\
\text { Planning and } \\
\text { Deployment }\end{array}$ & Planning & Planning & $\begin{array}{l}\text { Strategic } \\
\text { management }\end{array}$ & Strategy \\
\hline 3 & Operation Focus & $\begin{array}{l}\text { Value Creation } \\
\text { Process }\end{array}$ & Process & Process & $\begin{array}{l}\text { Process } \\
\text { Management, } \\
\mathrm{R} \& \text { \& D and } \\
\text { Innovation }\end{array}$ & $\begin{array}{l}\text { Process, } \\
\text { Products and } \\
\text { Services }\end{array}$ \\
\hline 4 & Customer Focus & $\begin{array}{l}\text { Understanding } \\
\text { and Interaction } \\
\text { with Customers } \\
\text { and Markets }\end{array}$ & Customer & Customer & $\begin{array}{l}\text { Customer and } \\
\text { market Focus }\end{array}$ & \\
\hline 5 & $\begin{array}{l}\text { Measurement, } \\
\text { Analysis and } \\
\text { Knowledge } \\
\text { Management }\end{array}$ & $\begin{array}{l}\text { Information } \\
\text { Management, }\end{array}$ & Information & Information & $\begin{array}{l}\text { Information } \\
\text { Management }\end{array}$ & $\begin{array}{l}\text { Partnership } \\
\text { and } \\
\text { resources }\end{array}$ \\
\hline 6 & Workforce Results & $\begin{array}{l}\text { Individual and } \\
\text { Organization } \\
\text { ability } \\
\text { Improve }\end{array}$ & People & people & $\begin{array}{l}\text { Human } \\
\text { Resources and } \\
\text { Knowledge } \\
\text { Management } \\
\end{array}$ & People \\
\hline 7 & Results & Activity Results & Results & Results & Results & $\begin{array}{l}\text { Results } \\
\text { (People, } \\
\text { Customers, } \\
\text { Society and } \\
\text { Key) }\end{array}$ \\
\hline
\end{tabular}

(Source: Robin et. al., 2013)

After discussing the most commonly used business model in Malaysia, the next section is to explore Canvas Business Model. This model is introduced several years ago, but received great support and positive comments from the practitioners.

\section{Canvas Business Model}

Business Model Canvas is an innovative product from Alexander Osterwalder (2010) which has been implemented by well known company like Microsoft, Apple, Google, Lego, Facebook, and many others. This model is a compilation of the existing business models in the market, analyzed and modified to outfit the current scenario in the business management arena. This model has proven its success by the effectiveness to help organizations to improve business performance.

The advantages of Canvas Business Model is able to explore the functions, activities and process interlink and interlock within the business. It improved customer awareness, focus on value, identify risks and weaknesses. It also helps to manage resources activities and proactively assess the sustainability of business model. In short, Canvas Business Model is 
considered as the most innovative business model among all as it taken all possible consideration in running a business.

The Canvas Business Model is conducted by assessing the business criteria. Each business criteria are different, depending on the types and characteristic of the business model and business type. Figure 3.1 shows the Canvas business Model evaluation method through assessment of nine (9) business model criteria.

Table 2.0: Canvas Business Model Criteria

\begin{tabular}{|c|c|c|c|c|}
\hline \multicolumn{5}{|c|}{ The Business Model CANVAS } \\
\hline \multirow[t]{2}{*}{ Key Partners } & Key Activities & \multirow[t]{2}{*}{ Value Proposition } & $\begin{array}{l}\text { Customer } \\
\text { Relationships }\end{array}$ & \multirow[t]{2}{*}{ Customer Segments } \\
\hline & Key Resources & & Channels & \\
\hline \multicolumn{2}{|l|}{ Cost Structure } & \multicolumn{3}{|c|}{ Revenue Streams } \\
\hline
\end{tabular}

According to Table 2.0, the Canvas Business Model is assessing nine (9) criteria which involving key partners, key activities, key resources, value proposition, customer relationships, customer segments, channels, cost structure and revenue streams. Based on the evaluation of the nine criteria, one can easily examine his business model performance.

After exploration of the ECP business models in Malaysia, the next logical step is to evaluate the existing business model in ECP Malaysia.

\section{Evaluation of Existing ECP Business Models in Malaysia}

Based on the current practice of ECP in Malaysia, it is discovered that two business models are widely implemented in Malaysian ECP business, namely Traditional Business Model and Business Excellence Model. Moreover, some of the large ECP in Malaysia are examining Canvas Business Model as this model is currently famous in determining organizational strength to improve business efficiency. Therefore, three business models are identified, to explore the characteristic, strength and weakness in each particular model. An empirical review is conducted to three business models mentioned, the strength, weaknesses and the sources of literature are computed in Table 3.0.

Table 3.0: Evaluation of Existing ECP Business Models in Malaysia

\begin{tabular}{|c|c|c|}
\hline Business Models & Strength & Weaknesses \\
\hline Traditional & $\begin{array}{l}\text { - } \text { Easy and simple to conduct } \\
\text { - Suitable for small business } \\
\text { - Customer satisfaction based model }\end{array}$ & $\begin{array}{l}\text { - Business expansion is limited } \\
\text { - Unhealthy competition among the } \\
\text { ECP } \\
\text { - Inefficient use of investments }\end{array}$ \\
\hline Business Excellence & $\begin{array}{l}\text { - Assess business excellence core } \\
\text { values and concepts } \\
\text { - Assess the strengths and areas for } \\
\text { improvement } \\
\text { - Provide guidance to practitioners }\end{array}$ & $\begin{array}{l}\text { - Some assessment of BEM is not } \\
\text { relevant } \\
\text { - Organization tends to confuse in } \\
\text { which criteria to focus on }\end{array}$ \\
\hline Canvas & $\begin{array}{l}\text { - Explore functions, activities in the } \\
\text { business. } \\
\text { - Improved customer awareness, focus } \\
\text { on value, identify risks and } \\
\text { weaknesses. } \\
\text { - Manage resources activities and } \\
\text { proactively assess the sustainability } \\
\text { of business model } \\
\text { - Focus in profit generation }\end{array}$ & $\begin{array}{l}\text { - Required huge management team to } \\
\text { apply } \\
\text { - Extra investments are required for the } \\
\text { implementation } \\
\text { - Complicated and required continuous } \\
\text { training to staffs }\end{array}$ \\
\hline
\end{tabular}


Based on Table 3.0, three business models have their own strength and weakness. There is no suitable model for ECP in Malaysia unless necessary modification is conducted to suit the business core of ECP in Malaysia. The selection of existing business model for ECP or to create new business model is further justified in following section.

\section{Modification of ECP Business Model Core Values}

The major consideration of a business model is related to the suitability of the model core values to the characteristic of the business. The business model of ECP in Malaysia has not been thoroughly discussed in any other business economic research. The concern of a good business model for ECP in Malaysia has raised the attention of Board of Engineer Malaysia after the implementation of liberalization. With this, the selection of either existing business model or creation of new business model for ECP in Malaysia has to be carefully evaluated.

Based on the literature, there is no best fit model for the ECP in Malaysia. By referring to the existing practicing business model (Traditional Business Model and Business Excellence Model) to incorporate with Canvas Business Model, several criteria is selected to form new business model to suit the ECP business characteristic.

The development of new business model or renovating an established business model is often started with the consideration of the business to meet the requirement of the customers. A strong value propositions should be created by giving more focus on the behavior of the customers and the context of their usage of the product or service. This is usually required to make innovation into a business model enduring and effective (Don, 2012)

The selection of new business model core value is based on the suitability in ECP business. There are eleven (11) core value selected from the existing business models. The core values are customer segments, value propositions, channels, customer relationships, revenue streams, key resources, key activities, key partnerships, cost structure, leadership and innovative as shown in following figure.

\section{a) Customer Segments}

There are different groups of organizations in a business. Each types of organization represent the potential customers in the business. According to Canvas Business Model, the customer segments can be divided into five segments (5); mass market, niche market, segmented, diversified and multi-sided platforms (Alexander, 2010).

\section{b) Value Propositions}

The value proposition is the bundle of products and services that create value for the specific customer segment. The value involved might be in terms of quantitative (e.g. price, speed of service) or qualitative (e.g. design, customer experience) based on the requirement of the customers. In short, value propositions summarized the reason why the customer should buy a product or a service (Investopedia, 2014).

\section{c) Channels}

Channel is a process to bring the customers to meet their value propositions. The process involved five criteria, awareness, evaluation, purchase, delivery and after sales. The awareness of in the channel is referring to the products and services offered to customers. Next, help the customers to evaluate the organization value propositions. Then, allowed the customers to purchase specific product and service provided. Followed by evaluating the value propositions of the business model to identify which value propositions have been delivered to the 
customers. Finally, after sales is referring to the post purchase customers support. The channel helps a business organization to promote their product or services to the customers, identify the customers' needs and delivered suitable and best service to the customers. This philosophy of business criterion is applicable to every types of business in the market.

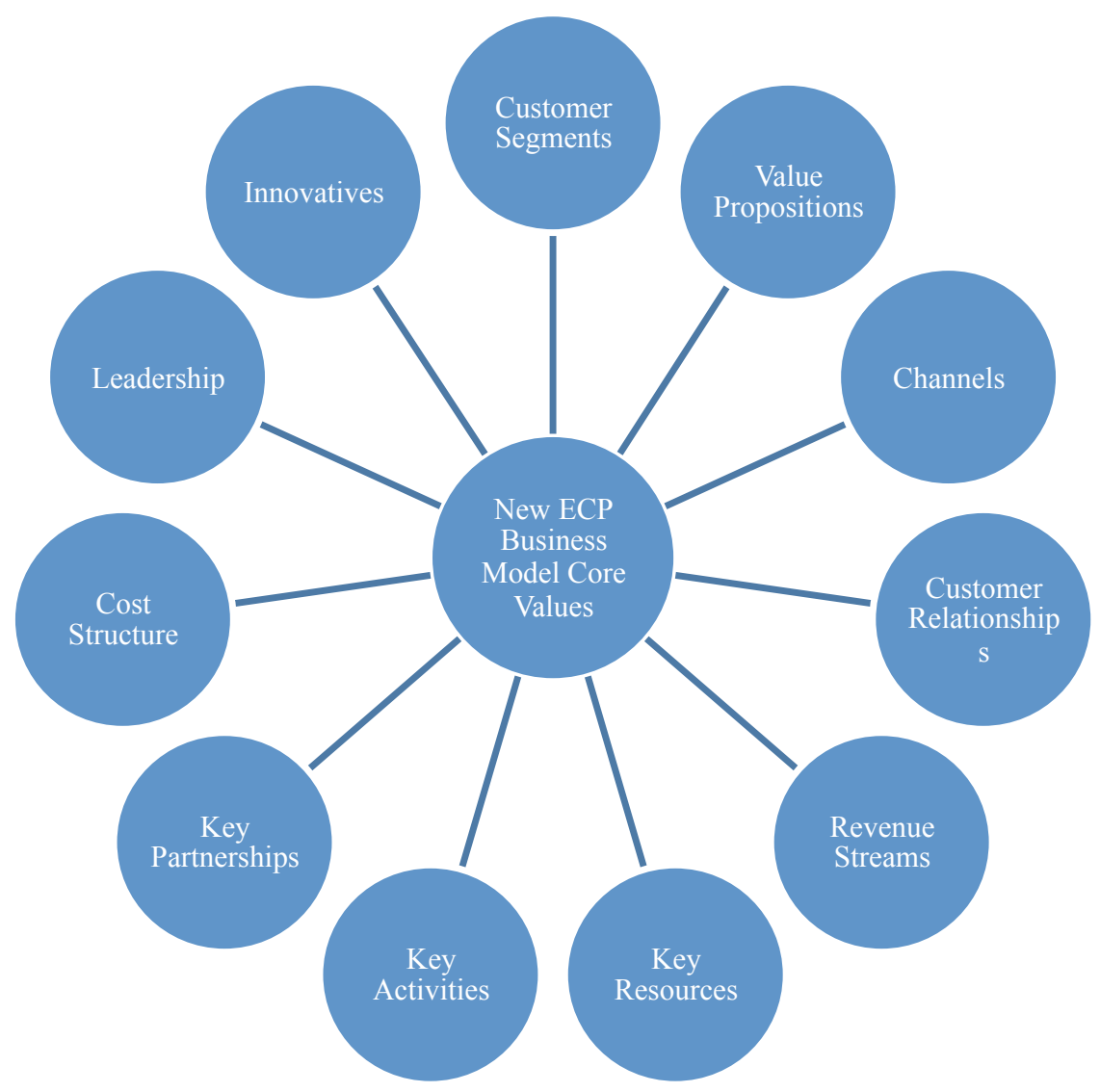

Figure 1.0: New ECP Business Model Core Values

\section{d) Customer Relationships}

Customer relationships referring to the types of relationships of a company establishes with specific customer segments. That is the way of the company deal with the existing customers. Normally there are four (4) types of relationships in business arena, namely personal assistance, self service, automated service and communities (Alexander, 2010; Entrepreneur, 2014)

\section{e) Revenue Streams}

Revenue streams are defined as the net profit generated from each customer segments.

\section{f) Key Resources}

Key resources are the most important assets required to make a business model work. There are four (4) types of key resources in a company, physical resources, intellectual resources, human resources and financial resources. Each resource plays an important role in business arena to determine a success in a particular business.

\section{g) Key Activities}

Key activities are referring to the compulsory procedure that keeps the business running. Basically, there are three (3) key activities to keep a business running, the production, problem solving and network. These activities are commonly seen in every type of business. 


\section{h) Key Partnerships}

Key partners are the network, financier, suppliers and partners that make a business works. One must identify who are the key partners in the business in order to prevent financial lost. This is essential as key partners are the optimizer of sales, risk reduction player and supporting to certain resources.

\section{i) Cost Structure}

Cost structure is the relative proportions of fixed cost, variable cost that incurred to a business. This is interrelated to the economies of scale and the scope of the business structure and production. Cost structure is usually used to determine product or services price. Thus, the cost structure concept is a management accounting concept in evaluating product price (Accounting Tools, 2014).

\section{j) Leadership}

Leadership in a business is essential to set direction and to create customer focus, clear and visible organizational values, and high expectations for the workforce. Leadership is crucial in running a business as it determined the direction of the business organization. This is especially true when the owner of the business of Chief Executive Officer (CEO) has a strong ability in leadership to organize the business. Different business thread might required different focus in leadership criteria, depends on the types of business, marketing method, size of business and etc (Michael and William, 2012).

\section{k) Innovation}

Innovation of a business model is to improve an organization's products, services, programs, processes and operations to create new value for the organization's stakeholders. There are four (4) criteria in innovation are value, pro activity, new plan and social capital to push forward a business. Similar to engineering consultancy based business models, innovation in these business models are able to enhance the creativity in marketing and delivery of the services.

After defining new ECP business model core values, the next logical step is to verify the appropriateness of the new business model core values to the practitioners. In view of that, a systematic methodology to conduct the verification is discussed in following section.

\section{METHODOLOGY}

This paper is adopt systematic samplings by reviewing the existing practices from selected domain with reference to particular journals and conference papers (Biedenbach and Muller 2010; Chan et al., 2009). The selected journals are mainly from top quality journal publishers which included: (1) American Society of Civil Engineers (ASCE); (2) Science Direct; (3) Emerald; (4) SAGE; and (5) various online sources to review the existing engineering service providers' business model.

This paper is conceptualized the new ECP business model in Malaysia through enhancing the care values of business model. As such, triangulation method is conducted in this study. Interview is conducted to verify the appropriateness of the new introduced business model core values to ECP in Malaysia. 4 interviewees are selected from the practitioners and 1 academician is selected to justify the concept of the development of new ECP business model. Quantitative analysis is used to analyze the appropriateness of the new introduced business model core values in this study. The analysis and discussion is shown in following section. 


\section{ANALYSIS AND DISCUSSION}

This section analyzed the data collected. Four practitioners and one academician are selected to justify the new business model core values for Engineering Consultancy Practices (ECP) in Malaysia. The introduction of the new business model core values is to enhance the existing traditional business model which is commonly practiced by the ECP in Malaysia. The summary of the interview session is computed in Table 4.0.

Table 4.0: Summary of Interviewees Comments and Rating

\begin{tabular}{|l|c|c|c|c|c|c|}
\hline Criteria & \multicolumn{3}{|c|}{ Interviewees } & \multirow{2}{*}{ Mean } \\
\cline { 2 - 6 } & $\mathbf{1}$ & $\mathbf{2}$ & $\mathbf{3}$ & $\mathbf{4}$ & $\mathbf{5}$ & \\
\hline Suitability of New Core Values & 4 & 5 & 4 & 5 & 4 & 4.4 \\
\hline Ease of Application & 4 & 4 & 3 & 4 & 4 & 3.8 \\
\hline Channel to Promote New ECP Business Model & 3 & 4 & 4 & 3 & 4 & 3.6 \\
\hline Ability to Apply in ECP Malaysia & 2 & 3 & 4 & 3 & 3 & 3 \\
\hline Ability to Improve ECP Business Performance & 4 & 4 & 4 & 4 & 4 & 4 \\
\hline Influences to ECP Business in Malaysia & 5 & 5 & 5 & 5 & 5 & 5 \\
\hline
\end{tabular}

* 1= Strongly Disagree; 5= strongly Agree

Interviewee 1 and 4 are concerned on the channel to promote the new ECP business model and the ability to apply the new business model in Malaysia. As the location of the ECP in Malaysia are setting up across thirteen states, divided into Pennisular Malaysia and Borneo Island. The channel to promote the ECP is an obstacle in the country. Moreover, the willingness to apply of the new ECP business model is greatly dependent on the practitioners themselves. Similar to interviewee 1 and 4, interviewee 5, the academician is concerning the ability to apply the new ECP business model in Malaysia. He suggested that Board of Engineer Malaysia should take part in promoting the new business model, at the same time organized campaign to raise awareness and educated the practitioners in conducting businesses in Malaysia. Apart from that, the comment on the 11 new ECP core values are shown in Figure 2.0

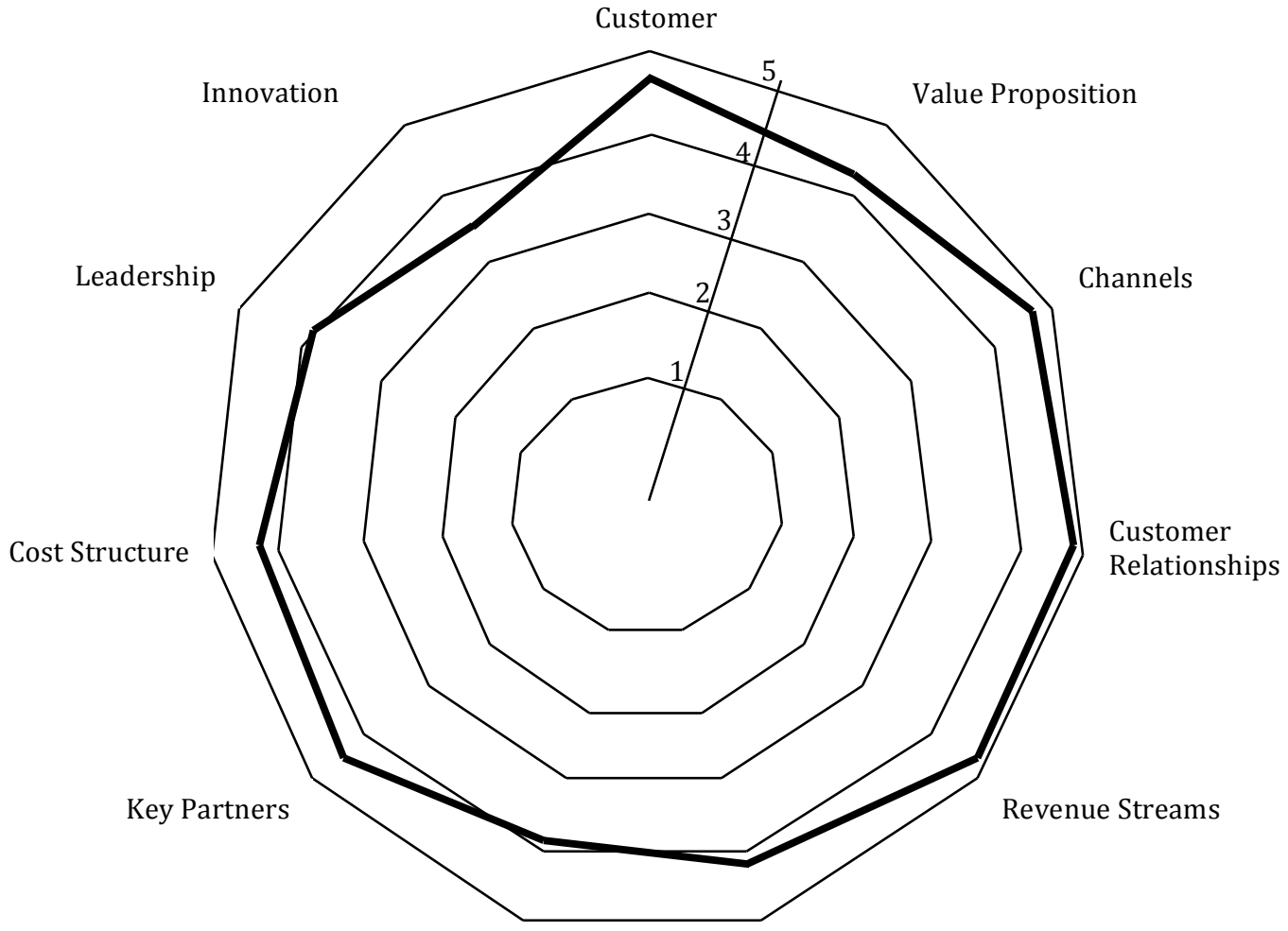

Key Activities

Key Resources

Figure 2.0: Evaluation of New ECP Business Core Values 
It is found that respondents are less agreed with the "innovation" in the new ECP core values. According to interviewee 3 , the innovation in the business model has less influence to the ECP due to the business nature. ECP is providing engineering consultancy services which is incorporated to architectural design. This has restricted the innovation of ECP in engineering design.

Other than that, respondents are agreed with the introduction of new business core values in ECP business model. As the development of the concept of new ECP business model is accepted by the practitioners and the academician, the study will be further carried out in analyzing each core values of the new ECP business model in the future undertaking study.

\section{CONCLUSION}

There are numerous types of business model in business academic studies. The selection of the business model is based on the suitability and types of the business conducted. Engineering Consultancy Practice (ECP) is still young in terms of business development in Malaysia. The liberalization has brought direct impact to the ECP development, creating competitiveness and flexibility to the ECP service providers. Therefore, the ECP in Malaysia today is facing greater challenges in sustaining their business.

The adoption of suitable business model is able to help ECP in managing the firm in a systematic way to ensure revenue stream. As the selection and suitability of the business model is relied on the eleven business core values, hence formation of best ECP business model could be generated by review the core values and criteria to suit the Malaysian consultancy industry.

\section{References}

Accounting Tools. (2004). Retrieved from: http://www.accounting tools.com/questions-and-answers/what-iscoststructural.html

Angkinand, A. P., Sawangngoenyuang, W., and Wihlborg, C. (2010). Financial Liberalization and Banking Crises: A Cross-Country Analysis. International Review of Finance. 10(2), 263-292.

ASEAN Secretariat (1995). AFTA Reader, vol. III, New Time Frame: Acceleration of Tariff Reduction. Jakarta, Indonesia.

ASEAN Secretariat (1999). AFTA Reader: Questions and Answers on the CEPT for AFTA: Volume II. ASEAN Secretariat, Jakarta.

Awojobi, O. (2013). Does Trage Openness and Financial Liberalization Foster Growth: An Empirical Study of Greek Economy. International Journal of Social Economics. 40(6), 537-555.

Biedenbach, T. \& Müller, R. (2011). "Paradigms in Project Management Research: Examples From 15 Years of IRNOP Conferences," International Journal of Managing Projects in Business, 4, 82-104.

Bogdanowicz, M. (1997). The Social Impacts Of Telecom Liberalisation In Europe. The Productivity Gains Hypothesis: How Do Corporate Users React? Telematics and Informatics. 14(4), 357-363.

Burguet, R., and Sempere, J. (2003). Trade Liberalization, Environmental Policy, and Welfare. Journal of Environmental Economics and Management. 46,25-37.

Business Dictionary. (2014). Retrived from: http://www.businessdictionary.com/definition/marketsegmentation.html

Chadda, R. (2002). GATS and Its Implications for Developing Countries: Key Issues and Concerns. United Nation: DESA Discussion Paper No.25. http://www.un.org/esa/desa/papers/2002/esa02dp25.pdf. (Accessed April 7, 2014). 
Chesbrough H. W., and Rosenblom, R. S. (2002). The Role of The Business Model in Capturing Value from Innovation: Evidence from Xerox Corporation's Technology Spinoff Companies. Industries and Corporate Change, 11. Pp. 533-534.

Chikhuri, K. (2013). Impact of Alternative Agricultural Trade Liberalization Strategies on Food Security in the SubSaharan Africa Region. International Journal of Social Economies. 40(3), 188-206.

David J. T., (2010). Business Models, Business Strategy and Innovation. Long Range Planning 43 (2010) 172-194.

DeCoster, J. (1998). Overview of Factor Analysis. Available from: http://www.stat-help.com/note.html.

Department of Statistic Malaysia, 2013. Gross Domestic Product At Current Prices - Quarterly 2011-2013.

Don S., (2012). Responding To Change And Pursuing Growth: Exploring The Potential Of Business Model Innovation In Australia. Report Of A Study Supported By The Australian Business Foundation.

Dvornika, D., and Sabolic, D. (2007). Telecommunication Liberalization and Economic Development in European Countries in Transition. Technology in Society, 29, 378-387.

Eddy, L. (2005). Trade Liberalization and Unemployment. Department of Economic and Social Affairs (DESA), New York, US.

Forbes, N. (2003). Technology and Indian Industry: What is Liberalization Changing? Technovation. 19, 403-412.

Holger Kett, Konrad Voigt, Gregor Scheithauer, Jorge Cardoso. (2009). Service Engineering in Business Ecosystems. German Federal Ministry of Economy and Technology.

Investopedia. (2014). Retrieved from: http://www.investopedia.com/terms/v/valueproposition.asp

Kaliappan, S. R. (2009). Malaysia's Commitments to Services Liberalization under the Framework of General Agreement on Trade in Services (Gats) and Sean Framework Agreement on Services (Afas). Integration \& Dissemination. 94-101.

Mayo, M. C., and G.S. Brown. (1999). Building a Competitive Business Model. Ivey Business Journal. 63 (3) 18-23.

Michael O'Malley, and William F. Baker. (2012). 12 Criteria of Effective Leadership. Perspectives. Sibson Consulting. Vol. 20 (3).

Mishra, P., and Das, D. K., (2013). Trade Liberalization and Wage Inequality in India: A Mandated Wage Equation Approach. India Growth and Development Review. 6, 113-127.

Morris, M., Schindehutte, M., and Allen, J. (2005). The Entrepreneur's Business Model: Toward a Unified Perspective. Journal of Business Research. 58, 726-35.

Nine Malaysia Plan (2006-2010). Retriened from: http://www.epu.jpm.my/rm9/html/english.htm

New Strait Time (2012). Retrived from: http://www.nst.com.my/latest/najib-announces-liberalisation-of-sixsub-sectors-1.172188.

Robin Mann, Musli Mohammad, Ma Theresa. (2013). Understanding Business Excellece: An Awareness Guidebook for SMEs. Asian Productivity Organization.

Steven Sander. (2013). The Professional Versus Business Model in Engineering Consulting. Retrived from: http://witandwisdomofanengineer.blogspot.com/2012/12/the-professional-versus-business-model.html

Union Budget, 2013. Government of India, Ministry of Finance, Annual Financial Statemet, Chapter 10, Services Sector, p210.

Xiao, G. Y., and Wang, K. C. P. (2011). Railway Liberalization of Passenger Transportation in Europe, Proceedings of the Third International Conference on Transportation Engineering (ICTE). 186-191.

Yang, H. Y. (2010). Carbon Emissions Control and Trade Liberalization: Coordinated approaches to Taiwa's Trade and Tax Policy. Energy Policy, 29, 725-734. 